\title{
Application of Hazard Analysis and Critical Control Point (HACCP) system in the Production and Sale of 'Fura da nono' in Ahmadu Bello University, Zaria, Kaduna State, Nigeria
}

\author{
Lawan, M. K ${ }^{1} *$., Oladipo, O. A ${ }^{1}$., Yusuf, M. S ${ }^{1}$, Woziri, O. A ${ }^{2}$., Aliyu, M. B ${ }^{1}$., Bashir, U. U . \\ ${ }^{\prime}$ Department of Veterinary Public Health and Preventive Medicine, \\ Ahmadu Bello University, Zaria, Nigeria \\ ${ }^{2}$ Department of Veterinary Microbiology, Ahmadu Bello University, Zaria, Nigeria
}

Accepted June, 2021 and Published July, 2021

\begin{abstract}
To ensure the safety of 'Fura da nono', a popular beverage widely consumed in the university campuses within Northern Nigeria, the HACCP system need to be applied. The study was carried out to assess the biological hazards associated with consumption of 'Fura da nono' using the Hazard Analysis and Critical Control Point system. Flowchart of the production processes was drawn and samples were collected and analyzed at different stages of production for total aerobic and coliform plate counts and fungi isolation. The results showed that grinded millet have a total aerobic plate counts (TAPC) ranged from $6.72 \log _{10}$ to $6.98 \log _{10} \mathrm{cfu} / \mathrm{mg}$, while the total coliform counts (TCC) ranged from $5.32 \log _{10}$ to $5.45 \log _{10} c f u / m g$. After sieving, the (TAPC) ranged from $6.45 \log _{10}$ to $6.99 \log _{10} \mathrm{cfu} / \mathrm{mg}$, while the (TCC) ranged from $5.23 \log _{10}$ to $5.59 \log _{10} \mathrm{cfu} / \mathrm{mg}$. All samples were positive for fungi growth after grinding and sieving. The result of (TAPC) after addition of hot water but before molding into shape ranged from $2.99 \log _{10}$ to $3.23 \log _{10} \mathrm{cfu} / \mathrm{mg}$, while the (TCC) ranged from $0.53 \log _{10}$ to $0.86 \log _{10} \mathrm{cfu} / \mathrm{mg}$. After molding the millet dough into shape the (TAPC) ranged from $2.98 \log _{10}$ to $3.43 \log _{10} \mathrm{cfu} / \mathrm{mg}$, while the (TCC) ranged from 0.78 $\log _{10}$ to $2.60 \log _{10}$ cfu/mg. All the samples collected after adding boil water and molding the millet dough into shapes turn out to be negative for fungi growth. The risk analysis, showed high risk at the level of millet grinding, molding of dough, blending with yoghurt and packing into containers. the study revealed that the stages post boiling of the ingredients with water and molding of the dough into round shapes are the most prone to contamination as such considered as critical control points in 'fura' production. It was concluded that there were high bacteria counts in 'fura' production with dangers of food borne illnesses when consumed. There is a need to improve hygienic practices especially at the critical points observed in the study.
\end{abstract}

Keywords: Application, Aerobic and Coliform counts, 'Fura da nono', HACCP and Risk analysis

\footnotetext{
*Corresponding author:

email: kaboskylawan@yahoo.com

Tel: +2348066793019
} 


\section{INTRODUCTION}

'Fura', a semi-solid cereal-based meal (1), is a delicacy among Hausa-Fulani people of West Africa, particularly in Nigeria where it forms a major component of most household meals. 'Fura' is produced principally from either millet (Pennisetum glaucum) or sorghum (Sorghum bicolor) flour in combination with some spices to give it taste (1). The mode of processing the raw materials may vary among different communities and or households, but the basic ingredient remains the same. The product has no standardized specifications for composition (ingredients and additives), shelf life and processing has remained a home-based or artisanal activity that is carried out with nonsophisticated equipment and techniques. Depending on the ethnic-orientation, 'fura' is usually consumed after either mashing it in fermented milk from lactating cows (popularly referred to as "Nono") or mashed in water before consumption in the form of porridge (2), with or without the addition of a sweetener such as sugar $(3,4,5)$. 'Fura' can be prepared and locally preserved for some days before taking it with 'nono'. However, many people prefer to use yoghurt to mix with 'fura'. This mixture (commonly called "Fura da nono") has high nutritional and cultural values because of the constituent of the milk which is rich in protein, carbohydrate, minerals and enzymes (6).

The preparation of 'fura' involves grinding of the millet or guinea corn after which other ingredients are added into. Producers add dried pepper (ground), African black pepper (ground), and ginger root (5) in small quantities and different combinations. This is then sieved and a little quantity of water is added and molded. Water is then boiled and poured on the molded dough and allowed to stand for about 5 minutes before the excess water is removed. The dough is then pounded with mortar and pestle and molded into smaller round shapes. A little flour is sprinkled on it afterwards.

There are many concerns about the hygiene of 'Fura da nono'. For instance, a lot of producers utilize well water from unhygienic sources as their source of water for production which could serve as a source of contamination. Also grains used are highly prone to contamination (7).

Hazard analysis and critical control point (HACCP) is a scientific and very effective approach in identification, assessment, control and prevention of hazards during food production, processing, manufacturing and preparation for assuring food safety for final consumption $(8,9)$. HACCP strategy identifies hazards associated with different stages of handling and preparation, assesses the relative risk and identifies point where control measures would be effective $(10,11)$. In order to guarantee the safety of 'Fura da nono' to consumers, it is necessary to adopt the concept of hazard analysis critical control point (HACCP) to identify the biological hazards associated with 'fura' production and suggest possible control measures that would be introduced at critical points, to ensure food safety and prevent public health hazards.

\section{MATERIALS AND METHOD}

\section{Study Area:}

The study was carried out at Ahmadu Bello University, Zaria Main Campus, Kaduna State, Nigeria, located at Latitude110 03' 60'.00" N and Longitude 7' 41' 59.99" E.

\section{Study Design}

This is a cross sectional study to evaluate microbial safety of 'Fura da nono' which lasted for a period of three months. A survey of the different selling points of 'Fura da nono' within the study location was conducted to ascertain the location of the sellers, product packaging methods and sellers' willingness to participate in the study.

\section{Socioeconomic Description of the Producer}

The 'Fura' producer enrolled for this study lived in a fenced compound. Water for 'fura' preparation was obtained directly from a well within the compound. The producer also rear livestock (Goats, Sheep and poultry). 


\section{Hazard Analysis:}

Hazard analysis and critical control points were conducted on the product at all stages of production based on the methods of HACCP template as previously described (12). The producer was observed at each stage of the production process, and a flowchart of the preparation of 'fura' was drawn. Hazard analysis and critical control point was applied at each stage of production of 'fura' as shown on the flow chart (figure I). The hazard analysis stages consisted of observing the raw materials used, the production environment, 'fura' preparation and potential areas of contamination. Samples were taken at different stages of preparation and subsequently tested for fungi culture, total aerobic and coliform plate counts. This was done three time once a week for a period of three weeks.

\section{Samples Collection:}

The samples were collected at four stages of production three times in a week for a period of three weeks, making a total of 36 samples. Each sample type was collected into a sterile polythene bag and transported within one hour in an ice pack to the Bacterial Zoonoses Laboratory of the Department of Veterinary Public Health and Preventive Medicine Ahmadu Bello University, Zaria for culture and enumeration of total aerobic and coliform count, as well as isolation of fungi.

\section{Laboratory Procedures:}

Ten grams of each 'fura' sample was collected using a weighing balance and transferred into $90 \mathrm{mls}$ of $0.1 \%$ peptone water in sterile polythene bag, fastened and homogenized in a stomacher machine (stomacher laboratory blender 400) and by means of horizontal and vertical manual agitation for a few seconds. A 10 -fold serial dilution was carried out using $1 \mathrm{ml}$ of the homogenate and $9 \mathrm{ml}$ of sterile normal saline solution using the method of (13). Then $0.1 \mathrm{ml}$ of $10^{-6}$ dilution factor was inoculated into nutrient agar plate (Oxoid U.K.) and also $0.1 \mathrm{ml}$ was inoculated into MacConkey agar plate (Oxoid U.k.).
Cultures for Fungi: Fungi isolation was done using the methods of (14), by plating $0.1 \mathrm{ml}$ of $10^{-1}$ suspension on sabouraud dextrose agar plates using hockey sticks. The plates were kept at room temperature without inverting for 3-5 days. The organisms growing on the plates were observed and stained with lactophenol cotton blue stain and examined microscopically for fungal mycelia and spores. Mold grows with typical cotton-like appearance while yeast is moist, discrete and glistering.

Fungi colonies were taken from the media 24 hours for staining and stained using Gram stain and lactophenol blue. The Gram stain was used to view the morphology of the fungi from the sabaround's dextrose agar which were usually fungi and yeast.

Risk analysis of the production stages was done by modifying the methods of(9).

\section{Data Analysis}

The enumerated total coliform count and total aerobic plate count were converted to $\log _{10}$ and expressed as $\log _{10} / \mathrm{mg}$ and the mean value was calculated. 


\section{RESULTS}

Flowchart was drawn after observing different stage of 'fura' production (Figure 1).

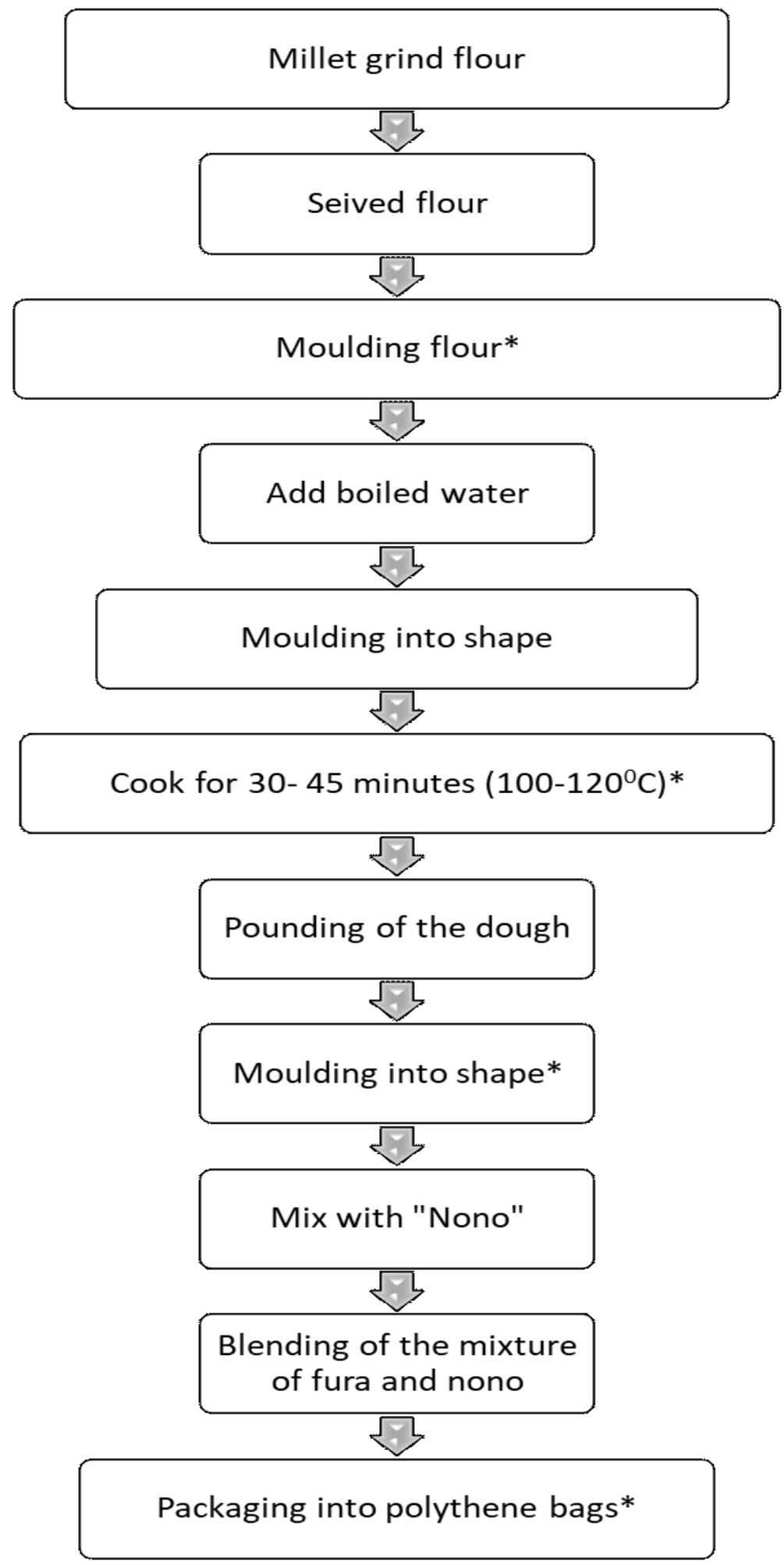

Figure I: flow chart of 'Fura da nono' production Key: * critical control points 


\section{Bacterial and Fungal Cultures}

Results revealed that earlier stages of production after grinding of millet into flour showed total aerobic plate counts (TAPC) ranged from $6.72 \log _{10} \mathrm{cfu} / \mathrm{mg}$ to $6.98 \log _{10}$ $\mathrm{cfu} / \mathrm{mg}$ while the total coliform counts (TCC) ranged from $5.32 \log _{10} \mathrm{cfu} / \mathrm{mg}$ to $5.45 \log _{10}$ $\mathrm{cfu} / \mathrm{mg}$. After sieving, the TAPC ranged from $6.45 \log _{10} \mathrm{cfu} / \mathrm{mg}$ to $6.99 \log _{10} \mathrm{cfu} / \mathrm{mg}$ while the TCC ranged from 5.23 $\log _{10} \mathrm{cfu} / \mathrm{mg}$ to $5.59 \log _{10}$ $\mathrm{cfu} / \mathrm{mg}$. All samples after grinding and sieving were positive for fungi growth (Table 1.0). The result of TAPC after addition of hot water before molding into shape ranged from $2.99 \log _{10}$ $\mathrm{cfu} / \mathrm{mg}$ and $3.23 \log _{10} \mathrm{cfu} / \mathrm{mg}$, while the TCC ranged from $0.53 \log _{10} \mathrm{cfu} / \mathrm{mg}$ to $0.86 \log _{10}$ $\mathrm{cfu} / \mathrm{mg}$. After molding the millet dough into shape the TAPC ranged from $2.98 \log _{10} \mathrm{cfu} / \mathrm{mg}$ to $3.43 \log _{10} \mathrm{cfu} / \mathrm{mg}$ while the TCC ranged from $0.78 \log _{10} \mathrm{cfu} / \mathrm{mg}$ to $2.60 \log _{10} \mathrm{cfu} / \mathrm{mg}$ (Table 1.0). All the samples collected after adding boiled water and molding the millet dough into shapes were negative for fungi growth.

Table 1.0: Total aerobic and coliform counts, and isolation of fungi at various Stages of ' $F u r a$ ' Preparation

\begin{tabular}{llll}
\hline Sampling points & \multicolumn{2}{c}{ Mean counts $\log _{10} \mathrm{cfu} / \mathrm{mg}$} \\
& week 1 & week 2 & week 3 \\
\hline After grinding of millet & \multicolumn{2}{c}{6.72} \\
TAPC & 6.87 & 6.98 & 5.45 \\
TCC & 5.45 & 5.32 & + \\
SDA & + & + & 6.45 \\
After sieving & & & 5.23 \\
TAPC & 6.85 & 6.99 & + \\
TCC & 5.43 & 5.54 & \\
SDA & + & + & 2.99 \\
After addition of boil water & & & 0.53 \\
TAPC & 3.02 & 3.23 & - \\
TCC & 0.78 & 0.86 & \\
SDA & - & - & 2.95 \\
Molding of flour into shape & & & 0.78 \\
TAPC & 3.18 & 3.43 & - \\
TCC & 0.98 & 2.60 & - \\
SDA & - & - & \\
\hline
\end{tabular}

Key

TAPC $=$ Total Aerobic Plate Counts

TCC $=$ Total Coliform Counts

SDA = Sabouraud Dextrose Agar

$+\quad=$ positive for fungi growth

- $\quad=$ Negative for fungi growth

The results of risk analysis showed that biological, physical and chemical hazards were encountered in production of 'fura' with biological hazard has highest occurrence in all the stages of production (Table 2.0) 
Table 2.0: Risk analysis of production stages of "Fura da nono"

\begin{tabular}{|c|c|c|c|c|c|}
\hline Production & Potential & & Assessment & & Control measure \\
\hline $\begin{array}{l}\text { Millet grind } \\
\text { flour }\end{array}$ & $\begin{array}{l}\text { Biological } \\
\text { Bacterial and } \\
\text { fungi pathogens } \\
\text { Physical } \\
\text { Dirt, sand and } \\
\text { stone particles }\end{array}$ & $\begin{array}{l}\text { Likelihood } \\
3\end{array}$ & $\begin{array}{l}\text { consequences } \\
3\end{array}$ & $\begin{array}{l}\text { Risk level } \\
\text { High }\end{array}$ & $\begin{array}{l}\text { Sorting out millet that } \\
\text { contain molds, washing } \\
\text { of the millet before } \\
\text { grinding into flour }\end{array}$ \\
\hline $\begin{array}{l}\text { Molding of } \\
\text { flour }\end{array}$ & $\begin{array}{l}\text { Biological } \\
\text { Bacterial and } \\
\text { fungi pathogens }\end{array}$ & 2 & 2 & medium & $\begin{array}{l}\text { Avoiding use of } \\
\text { contaminated container, } \\
\text { washing of hands with } \\
\text { soap before using it to } \\
\text { molding of the flour }\end{array}$ \\
\hline $\begin{array}{l}\text { Addition of } \\
\text { boiling water }\end{array}$ & $\begin{array}{l}\text { Chemical } \\
\text { Hard water, } \\
\text { heavy metals, } \\
\text { and seepage } \\
\text { from nearby } \\
\text { sewage system } \\
\text { Biological } \\
\text { Infectious } \\
\text { enteric bacteria }\end{array}$ & 1 & 2 & medium & Use clean potable water \\
\hline $\begin{array}{l}\text { Pounding of } \\
\text { dough }\end{array}$ & $\begin{array}{l}\text { Biological } \\
\text { Bacterial } \\
\text { pathogens }\end{array}$ & 2 & 2 & medium & $\begin{array}{l}\text { Use clean and } \\
\text { uncontaminated container } \\
\text { with pathogens, washing } \\
\text { of mortar and pestle } \\
\text { before and after pounding }\end{array}$ \\
\hline $\begin{array}{l}\text { Molding of } \\
\text { dough into } \\
\text { shape (fura) }\end{array}$ & $\begin{array}{l}\text { Biological } \\
\text { Bacterial } \\
\text { pathogens }\end{array}$ & 3 & 2 & High & $\begin{array}{l}\text { Washing of hand free } \\
\text { from germs, cover the } \\
\text { 'fura' after moldi ng not } \\
\text { expose it to dust and } \\
\text { pathogens }\end{array}$ \\
\hline $\begin{array}{l}\text { Blending fura } \\
\text { with yoghurt }\end{array}$ & $\begin{array}{l}\text { Biological } \\
\text { Bacterial and } \\
\text { fungi pathogens }\end{array}$ & 3 & 2 & High & $\begin{array}{l}\text { Washing of the blender } \\
\text { thoroughly before and } \\
\text { after blending the mixture } \\
\text { of 'fura' and yoghurt. Do } \\
\text { not blend any 'fura' that } \\
\text { already form molds on it }\end{array}$ \\
\hline $\begin{array}{l}\text { Packaging } \\
\text { container } \\
\text { (polythene bag) }\end{array}$ & $\begin{array}{l}\text { Biological } \\
\begin{array}{l}\text { Bacterial } \\
\text { pathogens }\end{array}\end{array}$ & 3 & 2 & High & $\begin{array}{l}\text { Use clean container free } \\
\text { from pathogens. Plastic } \\
\text { container with tight cover } \\
\text { will be more } \\
\text { appropriately to be used }\end{array}$ \\
\hline
\end{tabular}

\section{DISCUSSION}

Routine evaluation or surveillance of ready to eat food is very important to avoid food-borne outbreak in a community, especially on traditional food which microbial quality was never ascertain by food regulatory agency and also due to lack of standard operating procedures in the production of such foods. In this study there was high bacteria counts on both TAPC and TCC in all the critical stages of the 'fura' production (Table 1.0). This is of a serious public health concern. This is an indication that contamination can occur at all stages of 'fura' production and possible source of contamination include the presence of animals in the house as observed during the 
study, contamination from handlers, water source, presence of bacteria in the raw materials, utensils and environment. However other researchers (15) have shown that increase in bacterial contamination during food processing can result from cross contamination of contaminated utensils, or the instruments and facilities used in the production process. This finding is similar to work of (5) who got high bacterial count of $2.44 \times 10^{7} \mathrm{cfu} / \mathrm{g}$ from fura sold in wukari market in North-east of Nigeria, the process of 'fura' production as reported by (5) is similar to the one described in this study.

Flow chart of the 'Fura da nono' production consists of ten production stages with four stages identified as critical control points (figure I). According to codex alimentarius commission, critical control point is important stages of production in which control must be exerted to prevent unacceptable health risk or to avoid food safety hazard that can be eliminated or reduced to acceptable limit in the food production stages $(16,12)$. In all the five critical points identified in this study there were no application of heat or refrigeration in the stages except at one stage that involves heating (cooking of 30-45minutes), with up to 100 $120^{\circ} \mathrm{c}$ cooking temperature. This high temperature at this stage will kill large numbers of vegetative cells, but not heat resistant spores (10). Heat treatment of the molded flour into ball shape will not only improve the taste, smell, appearance and digestibility of the 'fura', but will also reduce the number of microorganisms, improve the keeping qualities by inhibiting molds, yeast and bacteria that promote food spoilage and infection. Thus, heat treatment is a practice aimed at improving the overall safety of food. This is what makes the cooking stage a very important Critical Control Point in production of 'fura' while the other three critical control points involves mixing of ingredients, water and milk (nono). It was observed in these three stages such as the molding of flour into ball shapes bare hands were used, therefore introduction of microbes and or other extraneous materials can easily occur in these three critical stages if not well controlled by the use of good hygienic practices.

The risk analysis of various steps of 'Fura da nono' production showed that biological, chemical and physical hazards can be encountered during production (Table 2.0). Biological hazards have the highest number of occurrence in the production steps and this finding concurred with reports of (17) that microbial health hazards are responsible for over $90 \%$ occurrence of global food-borne illness. Therefore, more attention is required in control of biological hazards in 'Fura da nono' from the raw material (millet and other ingredients) to the point of consumption. Most people that consume this beverage are not aware of the microbiological hazard of the 'Fura da nono' but are only concerned about the cleanliness of the personal selling the product at point of selling. This is similar to findings of (4) who reported that $37.56 \%$ consumers of 'Fura da nono' in Ilorin were more concerned with appearance and hygiene of the seller, than the appearance and smell of the product (16.59\%), retail environment $(21.46 \%)$ and the packaging $(24.39 \%)$ based on questioner survey.

In conclusion this study reveals that in the production process of 'Fura da nono' there were high total aerobic plate counts, coliform counts and fungi isolation which is of serious public health concern. These high aerobic and coliform counts are indications of poor hygienic practices and poor handling of the product which will promote transmission of food-borne illness to the public in consumption 
of such product. Five major CCPs were identified, where the stage of cooking for 3045 minutes was proven to serve as the most impactful control point.

Adequate enlightenment on the critical control points should be a necessity for producers of 'Fura da nono' and if correctly implement, the public health and economic advantages are enormous.

'Fura' producers should be educated by food regulatory agency on improvement of hygienic practices, good standard operating procedures in production and handling of the product and should also introduce proper packaging for the product to prevent post contamination of the product.

\section{REFERENCES}

1. Jideani, V. A., Nkama, I., Agbo, E. D. and Jideani, I. A. [2001]. Survey of 'fura' production in some northern states of Nigeria. Plant Food for Human Nutrition, 56: 23-26.

2. Filli, K. B., Nkama, I., Abubakar, U. M. [2010]. Influence of extrusion variables on some functional properties of extruded millet-soybean for the manufacture of fura. African Journal Food Science, 4: 342-352.

3. Owusu-Kwarteng, J. O., Debarh, K. T., Glover, R. L. K. [2010]. Process characteristics and microbiology of fura produced in Ghana, Nature Science, 8: 41-51.

4. Alimi, B. A., Oyeyinka, A. T. and Olohungbebe, L. O. [2016]. Socioeconomic characteristics and willingness of consumers to pay for the safety of fura de nunu in Ilorin, Nigeria. Quality Assurance and Safety of Crops and Foods 8(1): 81-86.

5. Ogodo, A. C., Agwaranze, D. I., Onudibia, M. E., Awache, I. and Agyo L. J. [2 01018 . Study on the bacteriological quality of fura sold in Wukari, North-East Nigeria. Journal Food Microbiology, 2(1): 24-29.

6. Muhib, M. I., Choudhry, M. A. Z. Easha, N. K., Rahman, M. M., Shammi, M., Fardous, Z., Bari, L., Uddin, K. M., Kurasaki, M. and Alam, K. M. [2016]. Investigation of heavy metal contents in cow milk samples from area of Dhaka, Bangladesh. International Journal of Food Contamination, 3:16.

7. Inabo, H. I., Ogbadu, L. J., Umoh, V. J ., A m e h, J . B ., [ [ [ $\left.\begin{array}{llll}2 & 0 & 0 & 0\end{array}\right]$. Microbiological quality of selected marketed condiments. Namoda Technscope Journal, 4, 20-30.

8. Pal, M. and Mahendra, R. [2015]. Sanitation in food establishment $1^{\text {st }}$ Ed Lambert Academic Publishing, Saarbruchen, Germany.

9. Hossain-Jany, N., Islam, R., Mazumder A. R. and Uddin, B. [2016]. Design and application of hazard analysis critical control point principles for typical frozen vegetables. Journal Food Safety and Hygiene, 2(1-2): 8-14.

10. Bryan, F. L. [1988]. Risks of practice of practices, procedure and processes that lead to outbreak of food-borne disease. Journal Food Protection, 44, 500- 512.

11. Ehir, J. E., Azuibike, M. C., Ubbaonu, C. N., Ayanwu, E. C., Ibe, K. M., [2001]. Critical control points of complementary food preparation and handling in eastern Nigeria. World Health Organization, 79, 423-433.

12. Mortimore, S. and Wallace, C. [1998]. HACCP: A practical approach, Chapman and Hall

13. Lawan, M. K., Temala, A., Bello, M. and Adamu, J. [2011]. Effect of Time of Meat Purchase on the Level of Microbial Contamination of Beef from Retail Point in Samaru Market, Zaria - Nigeria. Sokoto Journal of Veterinary Science, 9 (1): 18-21. 
14. Mailafia, S., Okoh, G. R., Olabode, H.

O. K. and Osanupin, R. [2017].

Isolation and identification of fungi

associated with spoilt fruits vended in

Gwagwalada market, Abuja, Nigeria.

Veterinary World, 10(4): 393-397.

15. Okolocha, E. C., Egwu, P. T. A., Umoh, J. U. and Luga, I. L. I. [2006]. Hazards and critical control points of yoghurt in Zaria, Nigeria. Nigerian Veterinary Journal, 27(3): 15-24.

16. Varzakas, T. [2016]. HACCP and ISO 2000: Risk assessment in conjunction with other food safety tools such as FMEA, Ishikawa diagrams and Pareto. Encyclopedia of Food and Health, www.sciencedirect,com

17. Pal, M., Gebregabiher, W. and Singh, R. K. [2016]. The role of hazard analysis critical control Point in food safety. Journal of Beverage and Food World, Vol 43-No 4 pp33-43 